\title{
Upaya Mengurangi Miskonsepsi pada Pembelajaran Fisika melalui Penerapan Model Creative Problem Solving
}

\author{
Yunita $^{1}$, Nana $^{2}$ \\ ${ }^{1}$ Mahasiswa Program Studi Pendidikan Fisika, Universitas Siliwangi \\ ${ }^{2}$ Dosen Program Studi Pendidikan Fisika, Universitas Siliwangi \\ Email : yunitauni217@gmail.com
}

\begin{abstract}
The purpose of this paper is to describe efforts to reduce misconceptions in learning physics through the application of creative problem solving models. This writing is motivated by the large number of students who still experience misconceptions in learning physics. For this reason, efforts need to be made to reduce misconceptions in learning physics by applying the creative problem solving model. The method used in this paper is the study of literature by studying some literature to be analyzed and made conclusions. The results of this paper indicate that the application of this creative problem solving model can be a solution in an effort to reduce misconceptions in learning physics. Because, creative problem solving models can improve students' understanding of concepts and skills, so students will better understand the concept by searching for themselves and solving problems independently but still not free from teacher guidance. Teachers can also actively involve students in the physics learning process.
\end{abstract}

Keywords: Misconceptions, Creative Problem Solving, Physics

ABSTRAK : Tujuan penulisan ini untuk mendeskripsikan upaya mengurangi miskonsepsi pada pembelajaran fisika melalui penerapan model creative problem solving. Penulisan ini dilatarbelakangi oleh banyaknya peserta didik yang masih terjadi miskonsepsi pada pembelajaran fisika. Untuk itu perlu ada upaya untuk mengurangi miskonsepsi pada pembelajaran fisika yaitu dengan penerapan model creative problem solving. Metode yang digunakan dalam penulisan ini adalah studi kepustakaan dengan mengkaji beberapa literatur untuk dianalisis dan dibuat kesimpulan. Hasil penulisan ini menunjukkan bahwa penerapan model creative problem solving ini dapat menjadi solusi dalam upaya untuk mengurangi miskonsepsi pada pembelajaran fisika. Karena, model creative problem solving dapat meningkatkan pemahaman konsep dan keterampilan peserta didik, sehingga peserta didik akan lebih memahami konsep dengan cara mencari sendiri dan memecahkan masalahnya secara mandiri namun tetap tidak lepas dari bimbingan pengajar. Pengajar juga dapat melibatkan peserta didik secara aktif dalam proses pembelajaran fisika.

Kata kunci : Miskonsepsi, Creative Problem Solving, Fisika 


\section{PENDAHULUAN}

Dalam proses pembelajaran, peserta didik selalu diarahkan dan dituntut untuk bisa memahami materi pembelajaran dengan sebaik-baiknya. Namun, faktanya selama proses pembelajaran berlangsung peserta didik tidak selalu menyerap dan memahami informasi yang telah disampaikan dengan sepenuhnya, terlebih lagi pada mata pelajaran Fisika yang memuat banyak konsep ilmiah dan dianggap sebagai sesuatu yang menakutkan bagi peserta didik. Hasil-hasil penelitian yang telah dilakukan dalam dua dasawarsa terakhir ini dalam bidang pengajaran fisika, menunjukkan bahwa salah satu sumber kesulitan utama dalam pelajaran fisika adalah akibat terjadinya kesalahan konsep atau miskonsepsi pada diri siswa (Van den Berg, 1991). Sehingga adakalanya apa yang dipahami siswa mengenai suatu konsep ilmiah sering kali berbeda dengan konsep yang dianut oleh para ahli fisika pada umumnya (Suparno, 2013). Ketidaksesuaian pemahaman konsep tersebut sering kali disebut sebagai miskonsepsi atau konsepalternatif.

Miskonsepsi yang terjadi pada peserta didik tidak terlepas oleh adanya penyebab atau sumber dari ketidaksesuaian konsep yang ada. Penyebab terjadinya miskonsepsi dapat disebabkan oleh beberapa sumber, yaitu dari diri siswa, guru, buku teks yang digunakan, konteks, dan cara mengajar guru (Suparno, 2013). Miskonsepsi ini muncul pada diri peserta didik dapat berasal dari pengalaman sehari-hari di alam sekitarnya. Sebelum mempelajari fisika, semua peserta didik telah mempunyai pengalaman dengan peristiwa-peristiwa fisika, misalnya benda jatuh bebas, aliran listrik, energi, tumbukan, dan lain-lain. Dengan pengalaman itu maka yang ada dibenak para peserta didik sudah terbentuk suatu dugaan dan teori sendiri mengenai peristiwa-peristiwa fisika tersebut, yang sudah tentu dugaan dan teori yang terbentuk tersebut belum tentu benar

Hikmah (2009) menyatakan bahwa penerapan pembelajaran creative problem solving dapat meningkatkan hasil belajar fisika dan aktivitas belajar siswa. Membiasakan peserta didik untuk mencari sendiri jawaban dari persoalan yang diberikan dapat meningkatkan pemahaman konsep dan bahkan keterampilan komunikasi peserta didik dalam pembelajaran fisika karena pada model creative problem solving telah menggunakan pemusatan pada pengajaran dan keterampilan dalam pemecahan masalah, dan juga telah diikuti dengan penguatan keterampilan. Ketika peserta didik diberikan suatu persoalan maka peserta didik dapat melakukan dan mengembangkan keterampilan memecahkan masalah untuk memilih dan memaparkan ide serta pemikirannya. Siswa tidak hanya menggunakan cara menghafal tanpa proses berpikir, tetapi menggunakan keterampilan memecahkan masalah yang mengembangkan proses berpikir (Pepkin, 2004).

Pendekatan dalam model kreatif dalam memecahkan masalah adalah dengan melihat potensi masing-masing peserta didik yang dikaitkan dengan gaya belajar. Oleh karena itu, diharapkan dengan menggunakan model pembelajaran creative problem solving dapat mengurangi miskonsepsi pada pembelajaran fisika.

\section{METODEPENELITIAN}

Metode yang digunakan dalam penulisan ini berupa studi kepustakaan. Data dikumpulkan untuk dianalisis kemudian disajikan dalam hasil dan pembahasan agar dapat dibuat kesimpulan.

\section{HASIL DAN PEMBAHASAN}

\subsection{Creative ProblemSolving}

Menurut Isaksen (1995) model CPS merupakan suatu rancangan kerangka metodologis dalam memecahkan suatu masalah dengan menggunakan kreativitas dalam pencapaian tujuan, mengatasi hambatan dan meningkatkan keterampilan berpikir kreatif. Asikin dan Pujiadi (2008) dalam penelitiannya memperlihatkan bahwa dalam model pembelajaran ini peserta didik aktif untuk menemukan solusi dari masalah secara kreatif, juga aktif berinteraksi dengan peserta didik lain melalui kegiatan diskusi kelompok maupun diskusi kelas serta presentasi di depankelas.

Valqui Vidal dalam Nana (2018) Model pembelajaran sebagai upaya untuk meningkatkan keberhasilan belajar siswa. Penerapan model dapat disesuaikan dengan kemampuan, sarana dan prasarana yang berkaitan dengan proses pemecahan masalah. Pemecahan masalah yang membutuhkan kreativitas dengan mendefinisikan berbagai pertanyaan untuk diselesaikan dan dicari solusinya. Penting sekali dalam memahami struktur masalah dengan berbagai pemikiran kreatif. Proses pemecahan masalah melibatkan pengalamanbaru 
yang secara logis di susun dengan sistematis. Ridong $\mathrm{Hu}$ et al. (dalam Nana, 2018) Masalah juga perlu dilihat dan diketahui kebenarannya. Basadur et al. (dalam Nana, 2018) Langkah-langkah dalam model creative problem solving antara lain sebagai berikut; proses pemecahan masalah dengan kreatif dengan menyeleksi informasi baru, masalah yang telah diidentifikasi kemudian di konsep secara komprehensif, proses masalah yang telah di konsep untuk menemukan solusi dari masalah yang nyata.

\subsection{Miskonsepsi}

Ilmu Fisika yang sebagian besar bersifat abstrak dan memerlukan penalaran yang cukup tinggi, sehingga di dalam mempelajarinya menyulitkan siswa dalam menggambarkan kedalam bentuk yang sebenarnya, dalam memahami konsep-konsepnya serta dapat menjadi verbalisme, hafal kata-katanya tetapi tidak mengerti arti sebenarnya. Ketidakmampuan tersebut menimbulkan miskonsepsi bagi siswa dalam mempelajari konsep-konsep Fisika (Nana, 2018). Miskonsepsi didefinisikan sebagai kesalahan pemahaman yang mungkin terjadi selama atau sebagai hasil dari pengajaran yang baru saja diberikan, berlawanan dengan konsepsi-konsepsi ilmiah yang dibawa atau berkembang dalam waktu lama (Mosik, 2010). Van Den Berg (1991) menjelaskan bahwa miskonsepsi adalah pola berpikir yang konsisten pada suatu situasi atau masalah yang berbeda-beda tetapi pola berpikir itu salah. Atau dengan kata lain konsepsi siswa bertentangan dengan konsep fisikawan, biasanya menyangkut hubungan antarkonsep.

\subsection{PembelajaranFisika}

Pembelajaran adalah proses interaksi peserta didik dengan pendidik dan sumber belajar pada suatu lingkungan belajar. Pembelajaran merupakan bantuan yang diberikan pendidik agar dapat terjadi proses perolehan ilmu dan pengetahuan, penguasaan kemahiran dan tabiat, serta pembentukan sikap dan kepercayaan pada peserta didik. Dengan kata lain, pembelajaran adalah proses untuk membantu peserta didik agar dapat belajar dengan baik.

Fisika adalah sains atau ilmu alam yang mempelajari materi beserta gerak dan perilakunya dalam lingkup ruang dan waktu, bersamaan dengan konsep yang berkaitan seperti energi dan gaya. Salah satu ilmu sains paling dasar, tujuan utama fisika adalah memahami bagaimana alam semesta bekerja. Jadi, pembelajaran fisika adalah proses interaksi yang terjadi antara peserta didik dengan pendidik dengan pelajaran fisika pada suatu lingkungan belajar misalnya di sekolah.

Fisika merupakan mata pelajaran yang dapat menumbuhkan kemampuan pemecahan masalah siswa. Oleh karena itu, dalam pembelajaran fisika siswa dituntut untuk membangun dan menemukan sendiri pengetahuannya sehingga dapat memecahkan masalah fisika seperti pemahaman konsep fisika sehingga tidak terjadi miskonsepsi.

\subsection{Upaya Mengurangi Miskonsepsi Pada Pembelajaran Fisika Melalui Penerapan Model Creative Problem Solving}

Salah satu masalah dalam proses pembelajaran fisika yaitu adanya kesalahan dalam pemahaman konsep atau miskonsepsi sehingga diperlukan upaya yang dapat mengurangi permasalahan tersebut. Salah satu cara yang dapat diupayakan yaitu dengan mendukung dan mengembangkan peserta didik menjadi lebih kreatif dan memiliki keterampilan dalam berkomunikasi juga keterampilan dalam memecahkan masalah. Keterampilan yang harus dimiliki oleh siswa berkaitan dengan penalaran verbal-numerik, pemikiran secara abstrak, mengingat informasi sesuai dengan keabsahan data (Cetinkaya, 2014). Pengembangan keterampilan peserta didik dapat melalui berbagai inovasi dalam pembelajaran salah satunya dengan menggunakan model yang tepat dan sesuai dengan karakteristik peserta didik juga sesuai dengan yang diharapkan oleh pengajar. Salah satu model yang sesuai untuk meningkatkan daya kreatif peserta didik yang diharapkan dapat mengurangi miskonsepsi pada pembelajaran fisika yaitu dengan model creative problem solving. Herlawan \& Hadija (2017) mengatakan bahwa model creative problem solving juga memberikan kesempatan kepada siswa untuk lebih aktif dalam membangun sendiri pengetahuannya dan mengembangkan pikiran dalam memahami masalah, menyelesaikan masalah, dan menjawab masalah secara sendiri, berdiskusi dalam kelompok dan menyalurkan pendapat secara optimal. Danties dalam Mayasari, Halim, \& Suhrawandi (2013) bahwa model creative problem solving menjadikan siswa sebagai 
pusat pembelajaran sehingga model ini mampu membuat siswa lebih aktif dalam pembelajaran.

Model creative Problem solving selain dapat meningkatkan kemampuan peserta didik untuk berpikir kreatif juga dapat meningkatkan kemampuan peserta didik dalam menyelesaikan masalah, serta dapat meningkatkan kemampuan komunikasi peserta didik seperti contohnya dengan melakukan presentasi. Pada model creative problem solving digunakan pemusatan pada pengajaran dan keterampilan pemecahan masalah, yang diikuti dengan penguatan keterampilan. Ketika peserta didik dihadapkan pada suatu permasalahan seperti adanya miskonsepsi materi fisika maka peserta didik dapat melakukan keterampilan memecahkan masalah untuk memilih dan mengembangkan ide serta pemikirannya. Namun, tidak terlepas juga dari komunikasi dengan pengajar untuk mengurangi adanya kesalahan konsep seperti misalnya antara konsep yang memang sudah ada dengan konsep yang dialami peserta didik di kehidupansehari-hari.

\section{PENUTUP}

Berdasarkan hasil studi kepustakaan, bahwa model creative problem solving dapat menjadi salah satu upaya untuk mengurangi miskonsepsi pembelajaran fisika. Model creative problem solving dapat meningkatkan pemahaman konsep dan keterampilan peserta didik. Penerapan model creative problem solving dalam upaya mengurangi miskonsepsi ini telah memenuhi indikator keberhasilan, dimana model creative problem solving dapat meningkatkan aktivitas belajar peserta didik. Sehingga, dengan meningkatnya keterampilan peserta didik maka akan menambah semangat untuk mempelajari konsep yang telah ada dan terjamin keabsahannya khususnya konsep pada pembelajaran fisika dan pengajar dapat mengikut sertakan peserta didik secara aktif dalam proses pembelajaran.

\section{UCAPAN TERIMAKASIH}

Terima kasih kepada semua pihak yang mendukung dan membantu dalam penyusunan artikel ini. Terima kasih kepada Dr. Nana, M.Pd. yang telah membimbing dalam penyusunan artikel ini.

\section{DAFTAR PUSTAKA}

Cetinkaya, C. (2014). The effect of gifted students creative problem solving program on creative thinking. Social and Behavioral Sciences, 116, 3722-3723.

Doi: 10.1016/j.sbspro.2014.01.830. Errington

Herlawan, \& Hadija. (2017). Peningkatan Kemampuan Pemecahan Masalah Matematis Siswa Kelas VII Melalui Penerapan Model Pembelajaran Creative Problem Solving (CPS) Berbasis Kontekstual. Jurnal Penelitian Pendidikan dan Pengajaran Matematika, 3(1), 33- 38.

Hikmah, D., dan M. Natsir (2009). Penerapan Pembelajaran Berbasis Masalah Tipe Creative Problem Solving (CPS) untuk Meningkatkan Ketuntasan Belajar Fisika Siswa Kelas VIII-E SMP N 1 Ma'rang Kabupaten Pangkep. JSPF, $10,1-9$.

M. Asikin, \& Pujiadi (2008). Pengaruh Model Pembelajaran Creative Problem Solving (CPS) Berbantuan $\mathrm{Cd}$ Interaktif Terhadap Kemampuan Pemecahan Masalah Pada Peserta didik Sma Kelas X. Jurnal Lembaran Ilmu Kependidikan, 37(1), 37-45.

Mayasari, P., Halim, A., \& Suhrawandi, I. (2013). Model Pembelajaran Creative Problem Solving untuk Meningkatkan Pengusaan Konsep dan Keterampilan Generik Sains Siswa SMP. Jurnal Pendidikan Sains Indonesia,57-67.

Mosik., \& Maulana, P. (2010). Usaha Mengurangi terjadinya miskonsepsi fisika melalui pembelajaran dengan pendekatan konflik kognitif. Jurnal Pendidikan Fisika Indonesia. 6(1), 98-103.

Nana. (2006). Penggunaan Pendekatan Konflik Kognitif untuk Meremidiasi Miskonsepsi Pembelajaran Suhu dan Kalor. Surakarta : Universitas Sebelas Maret(UNS)

Nana. (2018). Penerapan Model Creative Problem Solving sebagai Inovasi Pembelajaran di Sekolah Menengah Atas dalam Pembelajaran Fisika. Seminar Nasional Fisika dan Aplikasinya.

S. G. Isaksen. (1995). On the Conceptual Foundations of Creative Problem Solving: A Response to Magyary Back, Basil Blackwell journal. 4(1).5263. 
Suparno, Paul. (2013). Miskonsepsi dan Perubahan Konsep dalam Pendidikan Fisika. Jakarta: Grasindo

Van Den Berg, Euwe. (1991). Miskonsepsi Fisika dan Remediasi . Salatiga: Universitas Kristen Satya Wacana(UKSW) 